\title{
Maldives: Report on Observance of Standards and Codes-FATF Recommendations for Anti-Money Laundering and Combating the Financing of Terrorism
}

This Report on the Observance of Standards and Codes on the FATF Recommendations for Anti-Money Laundering and Combating the Financing of Terrorism for Kuwait was prepared by a team of the International Monetary Fund using the assessment methodology adopted by the FATF in February 2004 and endorsed by the Executive Board of the IMF in March 2004. The views expressed in this document, as well as in the full assessment report, are those of the IMF team and do not necessarily reflect the views of the Government of Maldives or the Executive Board of the IMF.

Copies of this report are available to the public from

International Monetary Fund $\bullet$ Publication Services

700 19th Street, N.W. • Washington, D.C. 20431

Telephone: (202) 6237430 • Telefax: (202) 6237201

E-mail: publications@imf.org • Internet: http://www.imf.org

\section{International Monetary Fund Washington, D.C.}




\title{
INTERNATIONAL MONETARY FUND
}

\author{
MALDIVES \\ Report on the Observance of Standards and Codes (ROSC)—FATF Recommendations for \\ Anti-Money Laundering and Combating the Financing of Terrorism (AML/CFT) \\ Prepared by the Legal Department \\ Approved by Sean Hagan
}

July 2011 


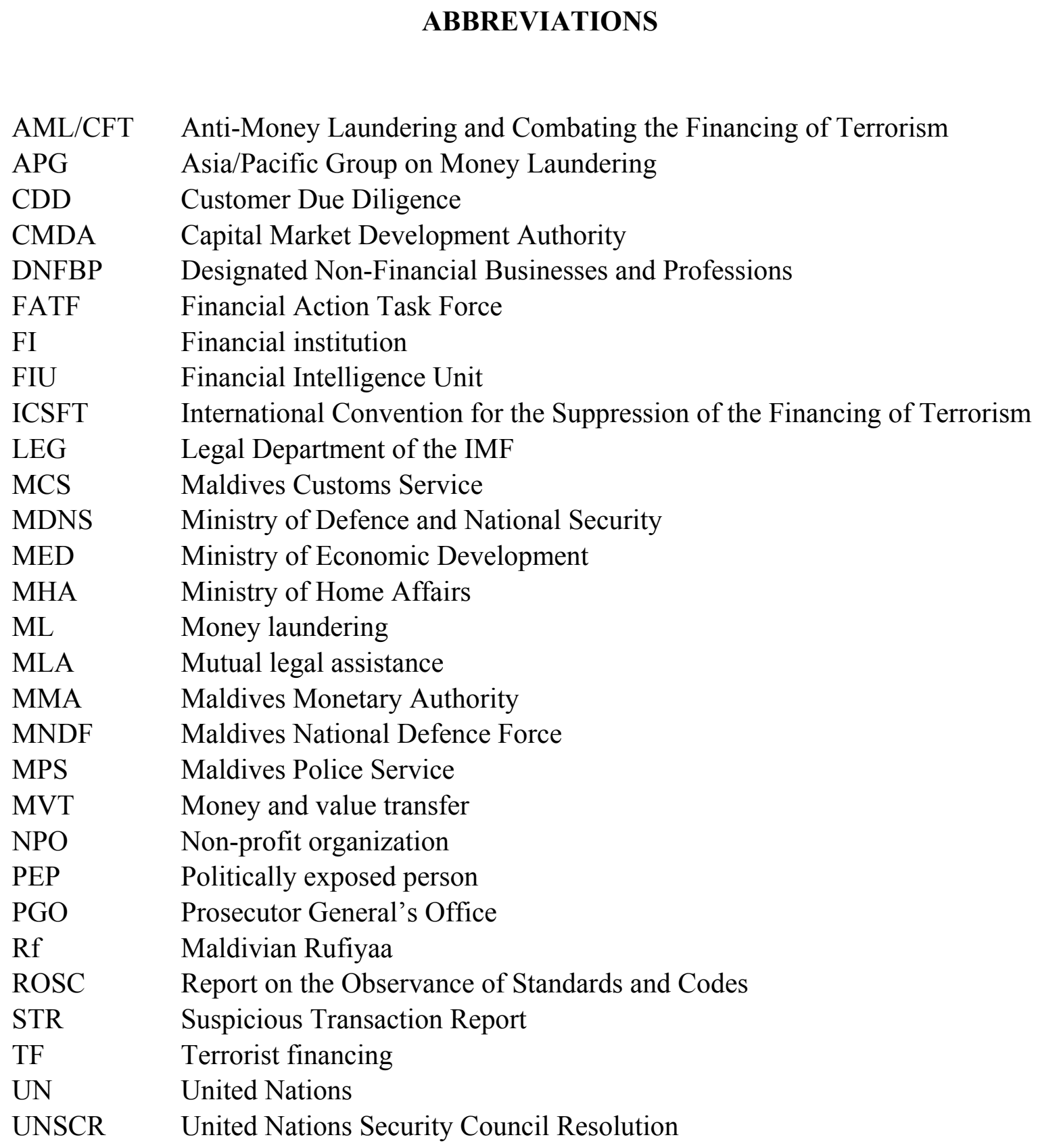




\section{A. Introduction}

1. This Report on the Observance of Standards and Codes for the FATF 40

Recommendations for Anti-Money Laundering (AML) and 9 Special Recommendations on Combating the Financing of Terrorism (CFT) was prepared by the International Monetary Fund. ${ }^{1}$ The report provides a summary of the AML/CFT measures in place in the Maldives and of the level of compliance with the FATF 40+9 Recommendations, and contains recommendations on how the AML/CFT system could be strengthened. The assessment is based on the information available at the time of the mission from October 17-28, 2010 and was conducted using the 2004 Assessment Methodology. Detailed Assessment Report (DAR) on which this document is based was adopted by the Asia/Pacific Group on Money Laundering (APG) plenary on July 20, 2011. The views expressed here, as well as in the full assessment report, are those of the staff team and do not necessarily reflect the views of the Government of the Maldives or the Executive Board of the IMF.

\section{B. Key Findings}

2. The financial sector of the Maldives, although small and not very developed, is susceptible to both money laundering (ML) and, to a lesser extent, terrorist financing (TF). While the authorities do not have estimates of the size of the crime economy, anecdotal evidence suggest that trafficking in illegal drugs and corruption alone produce significant amounts of illegal funds. There are also indications that financial resources have been raised in the country to fund terrorists and terrorist activities abroad.

3. Over the last years, the Maldives has taken steps to lay down the foundations of an AML/CFT framework. Institutional measures have been taken to set up a financial intelligence unit (FIU), and laws have been enacted to criminalize, albeit insufficiently, the laundering of the proceeds of drug-related offenses and impose basic AML/CFT preventive measures on banks. Regulations were adopted to address some AML/CFT aspects in the securities sector.

4. The current AML/CFT framework is very recent and in need of considerable improvements, both in terms of substance and implementation. Domestic inter-agency interaction relies on informal arrangements between the competent authorities rather than on more effective arrangements, the criminal legal framework is minimal, and most of the measures for the private sector are issued in the form of guidance rather than mandatory requirements. At the time of the assessment, no enforceable AML/CFT obligations were in

\footnotetext{
${ }^{1}$ The assessment team consisted of Ms. Nadine Schwarz (LEG, team leader and legal expert); Mr. Bert Feys (LEG, legal expert); Ms. Sisilia Eteuati (Asia/Pacific Group on Money Laundering, legal expert); Mr. Ashish Kumar (SEBI, India, financial sector expert) and Ms. Ke Chen (People's Bank of China, financial sector expert).
} 
place. Shortly thereafter, the authorities passed a new Banking Act which requires banks to implement basic AML/CFT measures such as customer identification and reporting of suspicious transactions to the FIU. Intermediaries in the securities sector are required to implement limited AML/CFT measures which became enforceable in April 2011. Financial institutions (FIs) other than banks and securities intermediaries, as well as designated nonfinancial businesses and professions (DNFBPs) active in Maldives are not subject to AML/CFT requirements. The authorities are working on a draft AML/CFT law which would impose more comprehensive AML/CFT preventive measures on FIs and DNFBPs, strengthen key agencies such as the FIU, and enhance domestic inter-agency cooperation and coordination.

\section{Legal Systems and Related Institutional Measures}

\section{The Maldives has criminalized ML, but only with respect to the proceeds of} offenses listed in the Drugs Act. The ML offense covers some aspects of the standard but not, for example, the conversion of criminal property and the concealment or disguise of the location, disposition and movement of that property. The authorities believe that, although not mentioned in the law, it is necessary to obtain a conviction for the predicate offense in order to secure ML charges.

\section{The framework for provisional measures and confiscation suffers from major} shortcomings and is rarely used. The types of property that may be confiscated are limited to tangible, corporeal assets with a direct link to the predicate offense, and there is no possibility to confiscate property of corresponding value.

7. The authorities' action against ML is not commensurate with the risk thereof. No investigation has taken place and no charges have been brought for ML under the Drugs Act. Drug trafficking is, however, one of the most frequent asset-generating crimes in the Maldives with an increasingly high number of the population using and or trafficking in illegal psychotropic substances. Anecdotal evidence suggests that it may generate up to US\$157,000 a day, or US\$57 million per year.

\section{Activities other than those listed in the Drugs Act do not constitute predicate} offenses for money laundering. All of the FATF-designated categories of offenses have been criminalized in the Maldives. However, asset generating crimes other than drug-related offenses such as corruption are not predicate offenses for ML and this constitutes a major shortcoming of the current AML/CFT framework.

9. TF is not criminalized in a separate and autonomous way. The provision of "finance and property" for the commission of a terrorist act only constitutes an ancillary offense (aiding and abetting) to the commission of that act. The offense is drafted in broad and undefined terms. This would entail that some aspects of the standard are covered, but it also creates considerable ambiguity in the authorities' mind as to the precise scope of the offense. No charges have ever been brought before the courts for this offense. 
10. There are no laws or procedures in place to freeze terrorist funds or assets of persons in line with United Nations Security Council Resolutions (UNSCR) 1267 and 1373 (and their successor resolutions), and those designated under the freezing mechanisms of other countries. The Maldivian central bank, the Maldives Monetary Authority (MMA), has sent the UNSCR Consolidated list to banks, credit card operators and money transfer businesses with an "instruction" to freeze the accounts of designated persons and entities, but there is no legal basis for the MMA (or any other authority) to require FIs to compare their list of clients with the Consolidated list (or any other list), and, in case of a positive match, to freeze and report the assets.

11. The Maldives suffered one terrorist attack in its capital, the Sultan Park bombing, in September $\mathbf{2 0 0 7}$ but reached no clear conclusion as to its funding. The intelligence gathered by Maldivian authorities and by foreign law enforcement agencies (both in respect to this attack and in relation to terrorist activities conducted in other countries) indicated that funds may occasionally be raised in Maldives to support terrorism abroad. There is, however, no information on the amounts involved.

12. Shortcomings in the overall criminal legislative framework, in particular with respect to criminal procedure, and the lack of resources of competent authorities make it challenging for the Maldives to fight effectively against ML and TF. The criminal justice process is slow and fraught with legal uncertainty mainly due to the paucity of criminal procedure rules. In addition, the AML/CFT system is hampered by a lack of capacity in the Maldives Police Service (MPS), the Prosecutor General's Office (PGO), and the judiciary.

13. The authorities set up an FIU within the central bank on the basis of a 2004 inter-ministerial agreement. The FIU did not become operational until 2006, when the MMA issued an "AML/CFT" Circular to all banks and other money transfer businesses instructing them to report suspicious transactions to the FIU. Despite its title, the Circular only addresses AML. The Circular does not have sound legal basis and is therefore not mandatory and not enforceable, but two banks and two money remitters nevertheless filed suspicious transactions reports (STRs) with the FIU in 2009. All four reports were analyzed by the FIU; two were closed because they contained no suspicious elements, one was forwarded to the MPS for further investigation, and one is still with the FIU.

14. The FIU lacks operational independence and has not been granted the necessary powers to conduct its functions in an effective manner. The FIU is the national center for the receipt and analysis of STRs filed by banks, but does not have the authority to disseminate financial intelligence; only the MMA has this authority. The analysis function is limited notably because the FIU has not been afforded access to all relevant information it would require to fulfill this function. While so far all the FIU's requests for information from other agencies have been complied with, there is no legal basis for these agencies to provide the requested information. The FIU does not have the authority to receive, analyze and 
disseminate STRs from entities other than banks. Since it became operational, the FIU has spear-headed the country's AML/CFT efforts and created a useful network of contacts with other key authorities.

\section{Preventive Measures - Financial Institutions (FIs)}

15. Banks and intermediaries in the securities sector are the only entities in the Maldives required to implement AML/CFT measures: Mandatory measures for banks were introduced in December 2010 (i.e. less than 8 weeks after the end of the assessment mission) with the enactment of the Banking Act. The Capital Market Development Authority (CMDA) 2010 Regulation on Anti-Money Laundering in Securities-Related Transactions (the CMDA 2010 Regulation) requires CMDA licensees to apply a number of AML/CFT measures, but, because the Regulation constitutes "other enforceable means" rather than primary or secondary legislation, it does not fully conform to the FATF standard.

16. The 2010 Banking Act sets out CDD and record keeping obligations for banks, as well as a requirement to report suspicious transactions to the FIU. Until December 2010, the only text that addressed AML measures was a non-enforceable 2006 MMA Circular to banks and other institutions involved in money transfer activities which provides general information on ML and lists some preventive measures that should be implemented.

17. While the issuance of the 2010 Banking Act is a very positive step in establishing a mandatory framework for AML/CFT preventive measures, the Act should be brought into line with the standard: The identification requirements in particular need to be strengthened (notably with respect to the identification of beneficial owners and the verification of the identity of all customers), and record keeping requirements should be more specific. Internal control requirements are very broad and have yet to be elaborated in regulation. Furthermore, the Banking Act is silent on a number of additional measures that banks should be required to undertake. There are, in particular, no obligations: to apply enhanced due diligence with respect to customers or beneficial owners who are politicallyexposed persons; to pay special attention to complex, unusual large or unusual patterns of transactions; to apply suitable measures while establishing correspondent banking relationships and to observe wire transfer rules in line with the standard.

18. AML/CFT measures for intermediaries in the securities sector were issued in 2010 and became enforceable in April 2011 (i.e. more than 8 weeks after the assessment), but their legal basis is, in many instances, insufficient to be in compliance with the standard. The CMDA 2010 AML Regulation set out some basic customer identification requirements and requires licensees to exercise special due diligence to extraordinary complex and large transactions that do not have a clear investment purpose, or that appear otherwise suspicious. It does not, however, require licensees to report suspicious transactions to the FIU. Moreover, record keeping and internal control requirements are too 
broad to be effective. Overall, considering that the CMDA Regulation is neither primary nor secondary legislation, it is insufficient to meet many of the requirements of the standard.

19. At the time of the assessment, monitoring and supervision of the banks' and securities intermediaries' compliance with AML/CFT requirements had not formally begun. The MMA and the CMDA, which are responsible for supervision of FIs in the banking and securities industries respectively, have been granted a range of powers to fulfill their functions, but have not started using them for AML/CFT purposes. This is due, in the banking sector, to the recent enactment of the Banking Act and, in the securities sector, to the fact that the CMDA Regulation provided the CMDA licensees with a 6 month timeframe (i.e. until April 2011) to comply with its provisions. The MMA, in the course of prudential supervision, nevertheless conducted some form of monitoring of banks' compliance with the 2006 AML Circular (although it was not mandatory) and suggested ways to improve the banks' nascent AML/CFT systems.

20. FIs other than banks and intermediaries in the securities sector are not subject to AML/CFT obligations. Insurance companies and intermediaries, finance companies, money remittance services providers, foreign exchange businesses and credit card companies therefore operate outside the AML/CFT framework. The authorities are planning on including some, if not all, of these institutions in the draft AML/CFT law.

\section{E. Preventive Measures - Designated Non-Financial Businesses and Professions}

21. Designated non-financial businesses and professions (DNFBPs) are not subject to AML/CFT obligations and to supervision of any kind. DNFBPs active in Maldives are lawyers, accountants and dealers in precious metals and stones ${ }^{2}$. Trusts cannot be established under current Maldivian law, but a draft Trust Law was prepared in 2008. According to the authorities, there is at the moment no trust business in Maldives, and no services to trusts formed in other jurisdictions, but the website of some Malé based law firms suggests otherwise. The draft AML/CFT legislation imposes AML/CFT obligations, including filing of STRs, on DNFBPs.

\section{F. Legal Persons and Arrangements \& Non-Profit Organizations}

22. The current framework does not ensure sufficient transparency of legal persons nor timely access to beneficial ownership and control information. Legal entities may take the form of a company, partnership, cooperative society or non-profit association. According the authorities' latest figures, there 8,657 legal entities in the Maldives most of which are companies. The Ministry of Economic Development holds some information on

\footnotetext{
${ }^{2}$ Casinos are outlawed under the Constitution and Shari'ah. The buying and selling of real estate is conducted by the seller and buyer themselves, or by lawyers. The latter also act as notaries and provide company formation services and other services to companies.
} 
registered legal entities, but this information is neither comprehensive nor updated in a consistent manner, and, in the absence of an electronic database, is not readily accessible.

23. The Maldives has a system of registration in place for NPOs but the information maintained by the registrar is insufficient to ensure sufficient transparency of NPOs. Information available at the registrar is limited to that pertaining to the purposes and objectives of registered NPOs, and the identity of their executive committees. There is no active or adequate system to promote effective supervision and monitoring of the NPOs, and no true understanding of risks of TF in the sector. The authorities suspect that NPOs have been misused to provide funding to terrorists aboard, but their suspicions remain unsubstantiated and no charges have ever been brought before the courts. There is no coordinated national strategy aimed at protecting NPOs from abuse for terrorist financing. The authorities are conducting a "scoping exercise" within the NPO sector, which will notably result in a redrafting of the Association Act, but the extent to which it will also look into the NPOs' vulnerability to TF risks is unclear.

\section{G. National and International Co-operation}

\section{A domestic cooperation mechanism specifically dedicated to AML/CFT policy} issues has been set up. A Coordination Committee for Combating Money Laundering and Terrorist Financing was created under the lead of the FIU and brings together representatives from the majority of the relevant authorities (including prosecutors, police, MMA, CMDA). It has not however delivered tangible results at this stage, with the exception of the responses to the detailed assessment questionnaire.

\section{There is no legislative framework regulating mutual legal assistance and} extradition. The types and range of measures that the Maldivian authorities may take on behalf of another State are mainly defined in memoranda of understanding concluded with other jurisdictions (copies of which were not provided to the assessment team). According to the authorities, very few requests for assistance have been addressed to the Maldives. Informal assistance however is more frequent.

\section{H. Other Issues}

26. Overall, the staff of the relevant Maldivian authorities should be increased and provided with training to increase AML/CFT expertise. The FIU has raised awareness on AML/CFT issues amongst the key agencies but there is a need for further AML/CFT training, in particular for the purposes of AML/CFT investigations and supervision.

27. It is important that key pieces of legislation be passed. In addition to comprehensive AML/CFT legislation, the draft revised Penal Code should be adopted and criminal procedure rules should be set out in law in order to enable the authorities to fight against ML and TF in an effective way. 


\section{Summary Table of Observance and Key Recommendations}

\begin{tabular}{|c|c|}
\hline $\begin{array}{l}\text { Largely compliant (LC): there a } \\
\text { Partially compliant (PC): the co } \\
\text { Non-compliant (NC): there are r } \\
\text { Not applicable (N/A): a requiren } \\
\text { country. }\end{array}$ & $\begin{array}{l}\text { is fully observed with respect to all essential criteria. } \\
\text { ly minor shortcomings, with a large majority of the essential criteria being fully met. } \\
\text { yas taken some substantive action and complies with some of the essential criteria. } \\
\text { r shortcomings, with a large majority of the essential criteria not being met. } \\
\text { or part of a requirement does not apply, due to the structural, legal or institutional features of a }\end{array}$ \\
\hline $\begin{array}{l}\text { FATF } 40+9 \\
\text { Recommendations } \\
\text { and Ratings }\end{array}$ & Key Assessor Recommendations \\
\hline & Legal System and Related Institutional Measures \\
\hline $\begin{array}{l}\text { Criminalization of Money } \\
\text { Laundering (ML) }\end{array}$ & $\begin{array}{l}\text { - Ensure that the predicate offenses for ML cover all serious offenses and not only } \\
\text { offenses under the Drugs Act. }\end{array}$ \\
\hline $\mathrm{NC}$ & including by ensuring that in all instances the criminalization of the categories of \\
\hline $\mathrm{NC}$ & $\begin{array}{l}\text { offenses is in line with the relevant international conventions and standards and by } \\
\text { criminalizing the ancillary offenses to ML. } \\
\text { - Ensure ML charges may also be brought in the absence of a conviction for the } \\
\text { predicate offense. } \\
\text { - Show effective use of the ML provisions. } \\
\text { - Allow for the intentional element of the offense of ML to be inferred from all } \\
\text { objective factual circumstances. } \\
\text { - Extend criminal liability and sanctions for ML offenses to legal persons other than } \\
\text { companies. }\end{array}$ \\
\hline $\begin{array}{l}\text { Criminalization of Terrorist } \\
\text { Financing }(\mathrm{TF})\end{array}$ & $\begin{array}{l}\text { - Criminalize TF autonomously in keeping with SR.II; and in doing so: ensure that } \\
\text { the provision and collection of fund for terrorist purposes is criminalized; ensure } \\
\text { that the use in full or in part of funds for TF purposes is criminalized; ensure that }\end{array}$ \\
\hline SR.II & $\begin{array}{l}\text { all acts in the nine anti-terrorism instruments are criminalized; ensure that the TF } \\
\text { offense applies to terrorist acts meant to compel international organizations; } \\
\text { criminalize financing of individual terrorists and terrorist organizations; define } \\
\text { "finance and property" so as to include all the elements of the definition of } \\
\text { "funds" as used in the ICSFT; ensure that it is not necessary to prove an actual use } \\
\text { of funds or a link to a specific terrorist act; and criminalize the attempt to commit } \\
\text { a TF offense. } \\
\text { - Make the TF offense a predicate offense for ML. } \\
\text { - Make sure that the TF offense applies to persons abroad who finance terrorist acts } \\
\text { in the Maldives. } \\
\text { - Permit the inference of the intentional element of the offense from objective } \\
\text { factual circumstances. } \\
\text { - For legal entities, allow for effective, proportionate and dissuasive sanctions other } \\
\text { than deregistration, and make them applicable also to entities not registered in the } \\
\text { Maldives. }\end{array}$ \\
\hline $\begin{array}{l}\text { Confiscation, freezing, and } \\
\text { seizing of proceeds of } \\
\text { crime }\end{array}$ & $\begin{array}{l}\text { - Ensure that confiscation can be applied to assets of every kind, whether corporeal } \\
\text { or incorporeal, moveable or immoveable, tangible or intangible, and legal } \\
\text { documents or instruments evidencing title to or interest in such assets, regardless } \\
\text { of whether these assets are held or owned by the defendant or a third party. }\end{array}$ \\
\hline $\mathrm{NC}$ & $\begin{array}{l}\text { - Allow for the confiscation of property of corresponding value, and of property } \\
\text { derived directly or indirectly from the proceeds of crime. } \\
\text { - Allow for freezing and seizing of property subject to confiscation with respect to }\end{array}$ \\
\hline
\end{tabular}




\begin{tabular}{|c|c|}
\hline & $\begin{array}{l}\text { all predicate crimes under the standard. } \\
\text { - Allow for the initial application to freeze or seize to be made ex parte or without } \\
\text { prior notice. } \\
\text { - Provide protection for the rights of bona fide third parties. } \\
\text { - Ensure that it is possible to prevent or void any action aimed at prejudicing the } \\
\text { ability of authorities to recover property subject to confiscation. } \\
\text { - Make effective use of the confiscation framework. }\end{array}$ \\
\hline $\begin{array}{l}\text { Freezing of funds used for } \\
\text { TF } \\
\text { SR.III NC }\end{array}$ & $\begin{array}{l}\text { - Adopt and implement measures, including legislative ones, to enable competent } \\
\text { authorities to seize and confiscate property that is the proceeds of, or used in, or } \\
\text { intended or allocated for use in, the financing of terrorism, terrorist acts or terrorist } \\
\text { organizations. } \\
\text { - Enact laws and procedures to freeze terrorist funds or other assets of persons } \\
\text { designated by the U.N. Al-Qaida and Taliban Sanction Committee in accordance } \\
\text { with S/RES/1267 and of persons under S/RES/1373(2001) as well as to examine } \\
\text { and give effect to, if appropriate, the actions initiated under the freezing } \\
\text { mechanisms of other jurisdictions. } \\
\text { - Establish effective systems for communicating actions taken under these freezing } \\
\text { mechanisms to FIs and other persons or entities that may hold targeted funds or } \\
\text { assets, and provide adequate guidance. } \\
\text { - Establish effective and publicly-known procedures for considering delisting and } \\
\text { for unfreezing funds or other assets of de-listed persons or entities, as well as for } \\
\text { unfreezing in line with SR II and for authorizing access to funds in accordance } \\
\text { with S/RES/1452(2002). }\end{array}$ \\
\hline $\begin{array}{l}\text { The Financial Intelligence } \\
\text { Unit (FIU) and its } \\
\text { functions }\end{array}$ & $\begin{array}{l}\text { - Establish on a sound legal basis the FIU as the centre for receipt, analysis and } \\
\text { dissemination of STRs from all reporting entities covered by the standard. } \\
\text { - Empower the FIU to have access, directly or indirectly and on a timely basis, to } \\
\text { relevant financial, administrative and law enforcement information. } \\
\text { - Enhance the overall quality and depth of analysis. } \\
\text { - Require the FIU to provide guidance on the manner of reporting. } \\
\text { - Ensure that the information held by the FIU is securely protected and disseminated } \\
\text { only in accordance with the law. } \\
\text { - Grant the FIU sufficient operational independence and autonomy by: ensuring } \\
\text { budgetary independence and autonomy in staff selection and retention; } \\
\text { determining the conditions for the appointment and dismissal of the FIU head; } \\
\text { securing FIU premises; allowing the FIU management to have an independent } \\
\text { decision making process for the receipt, analysis and dissemination of STRs. } \\
\text { - Require the FIU to publicly release periodic reports including statistics, typologies } \\
\text { and trends as well as information regarding its activities. }\end{array}$ \\
\hline $\begin{array}{l}\text { Law enforcement, } \\
\text { prosecution and other } \\
\text { competent authorities } \\
\begin{array}{ll}\text { R. } 27 \quad \text { NC } \\
\text { R. } 28 \quad \text { PC }\end{array}\end{array}$ & $\begin{array}{l}\text { - Ensure that ML and TF offenses are investigated and prosecuted. } \\
\text { - Provide a legislative basis for the MPS to postpone or waive the arrest of } \\
\text { suspected persons or the seizure of money. } \\
\text { - Enable its investigative agency to compel production of documents and records } \\
\text { that also pertain to associates, or to have a reasonable expectation of obtaining a } \\
\text { court order. } \\
\text { - Effectively use the power to compel documents and take witness testimony in ML } \\
\text { and TF investigations. }\end{array}$ \\
\hline $\begin{array}{l}\text { Cross Border Declaration } \\
\text { or disclosure }\end{array}$ & $\begin{array}{l}\text { - Introduce a compulsory cross-border currency declaration system or a disclosure } \\
\text { system in line with Special Recommendation IX. }\end{array}$ \\
\hline
\end{tabular}




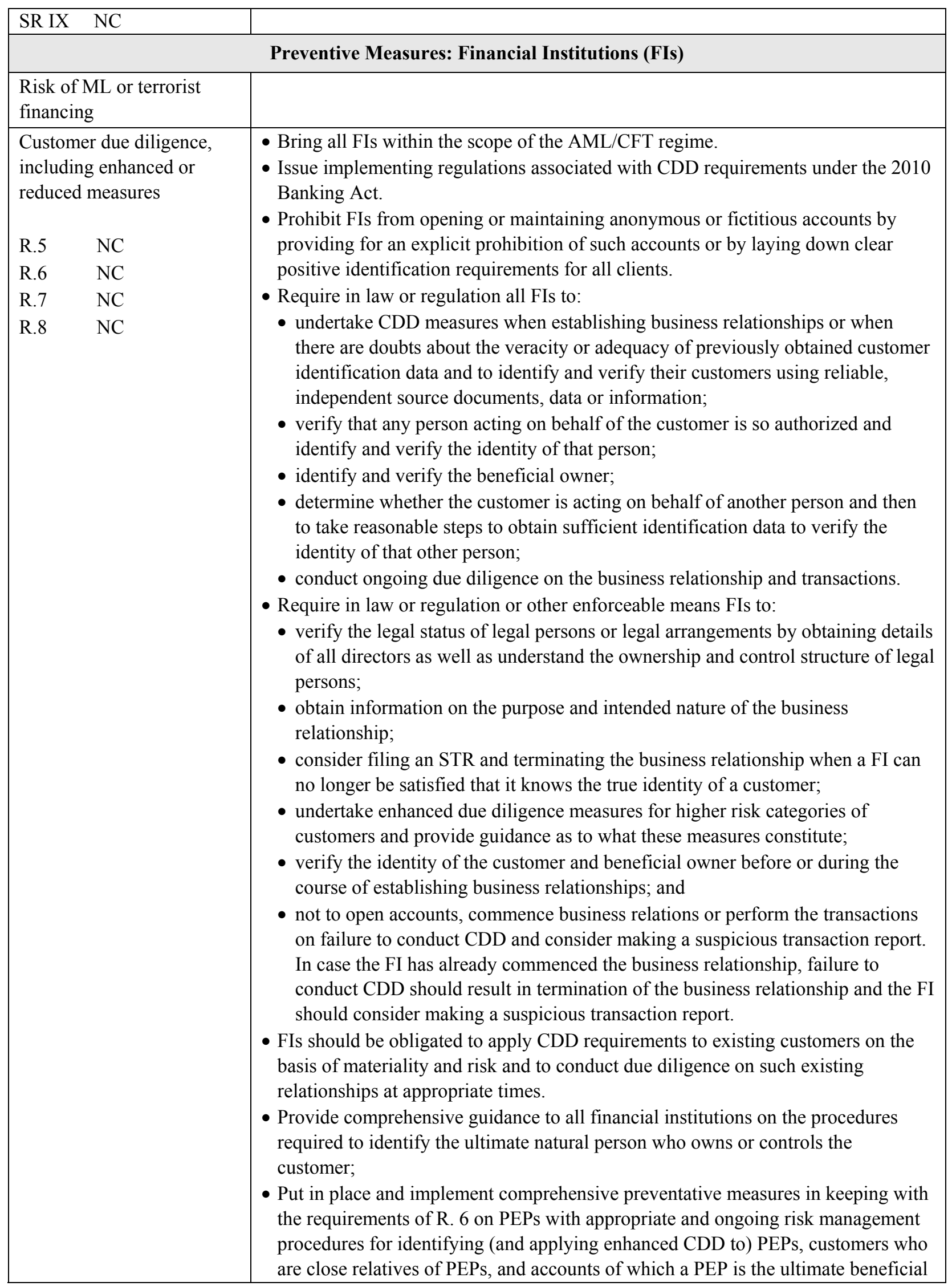




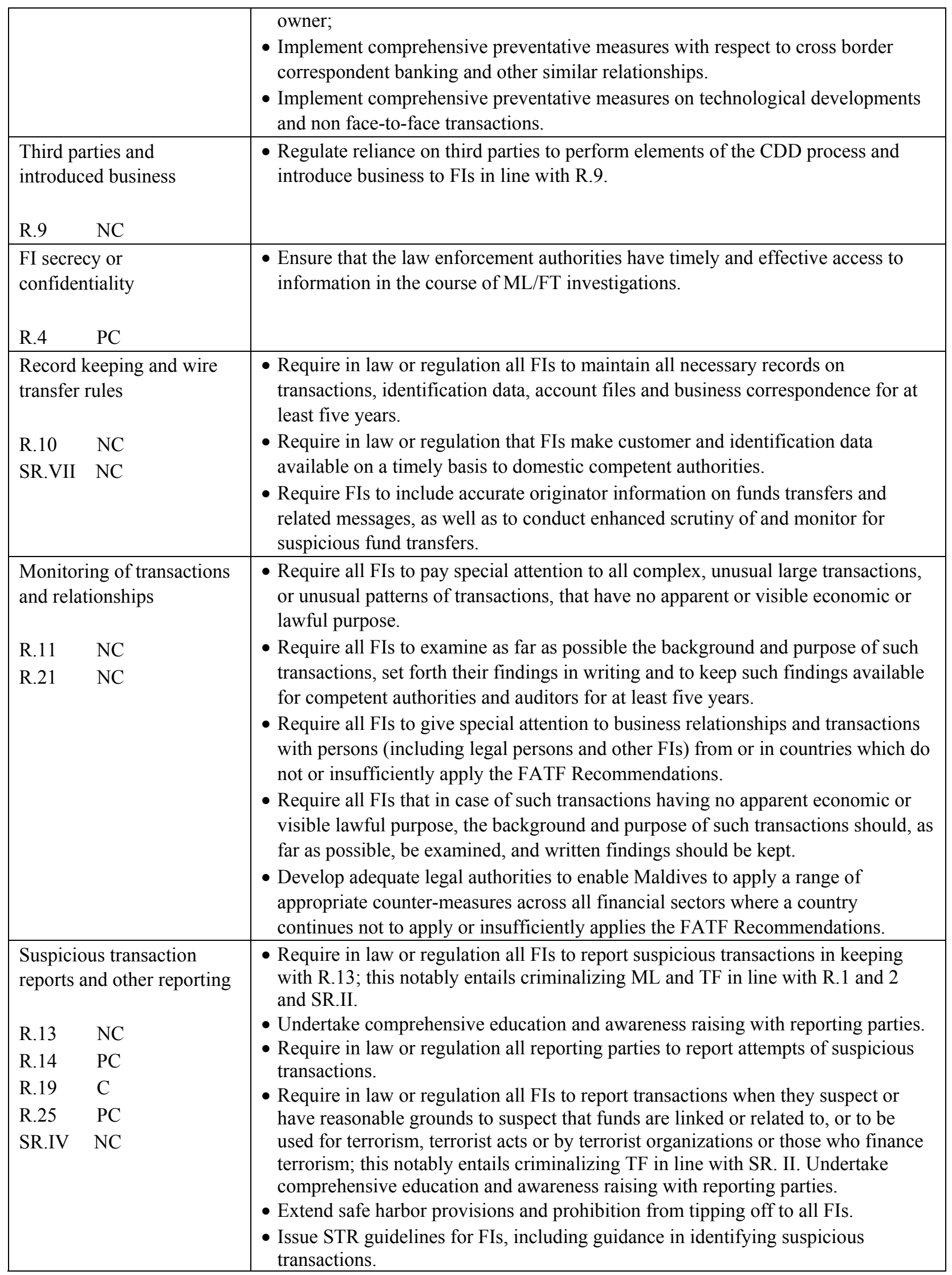




\begin{tabular}{|c|c|c|}
\hline $\begin{array}{l}\text { Internal } \\
\text { complia } \\
\text { foreign }\end{array}$ & $\begin{array}{l}\text { controls, } \\
\text { ace, audit and } \\
\text { ranches }\end{array}$ & $\begin{array}{l}\text { - Require FIs to have adequately resourced and independent audits to test } \\
\text { compliance with AML/CFT procedures. } \\
\text { - Lay down provisions relating to the overall role of compliance officer in FIs (other } \\
\text { than in the securities sector) and his access to relevant data and records so as to } \\
\text { enable him to effectively perform his functions. } \\
\text { - Require FIs to establish employee screening procedures when hiring new } \\
\text { employees. } \\
\text { - Require all FIs to provide adequate AML/CFT training to their staff. } \\
\text { - Support effective implementation of internal controls through comprehensive } \\
\text { AML/CFT supervision of all relevant sectors. } \\
\text { - Extend these requirements to foreign branches and subsidiaries of FIs. }\end{array}$ \\
\hline Shell ba & $\mathrm{PC}$ & $\begin{array}{l}\text { - Explicitly prohibit the establishment of shell banks, or explicitly require locally } \\
\text { incorporated banks to have physical presence (i.e. meaningful mind and } \\
\text { management) in the Maldives, and foreign branches to be affiliated with foreign } \\
\text { banks or financial groups that are subject to consolidated supervision. } \\
\text { - Prohibit FIs from engaging in or maintaining correspondent relationships with } \\
\text { foreign shell banks. } \\
\text { - Oblige FIs to satisfy themselves that respondent FIs in a foreign country do not } \\
\text { permit their accounts to be used by shell banks. }\end{array}$ \\
\hline $\begin{array}{l}\text { Supervi } \\
\text { system- } \\
\text { authorit } \\
\text { Role, fu } \\
\text { powers } \\
\text { sanction }\end{array}$ & $\begin{array}{l}\text { ory and oversight } \\
\text { competent } \\
\text { es and SROs } \\
\text { actions, duties and } \\
\text { including } \\
\text { s) }\end{array}$ & $\begin{array}{l}\text { - Designate by law the competent authority for AML/CFT regulation and } \\
\text { supervision of the insurance industry, finance leasing companies, MVT service } \\
\text { operators and money changers, and grant them with adequate powers. } \\
\text { - Introduce a wide range of effective, proportionate and dissuasive criminal and } \\
\text { administrative sanctions for FIs, including on their directors and senior } \\
\text { management, in sectors other than banks and securities. } \\
\text { - Introduce more effective and dissuasive criminal and administrative sanctions, } \\
\text { including those specifically applicable to directors and senior management, in the } \\
\text { securities sector. } \\
\text { - Require insurance intermediaries and MVT service operators to be licensed or } \\
\text { registered. } \\
\text { - Implement market entry and "fit and proper" requirements to existing banks and } \\
\text { insurance companies, and ensure beneficial owners of all FIs are "fit and proper". } \\
\text { - Conduct AML/CFT supervision of banks and the securities sector. } \\
\text { - Provide adequate guidance to all types of FIs, including information on current } \\
\text { ML and TF trends and techniques. }\end{array}$ \\
\hline $\begin{array}{l}\text { Money } \\
\text { services }\end{array}$ & alue transfer & $\begin{array}{l}\text { - Designate competent authorities responsible for licensing/registration and } \\
\text { regulation/supervision of the MVT service operators. } \\
\text { - Require in law or regulation that MVT service operators comply with AML/CFT } \\
\text { measures, including conducting customer due diligence, keeping records, } \\
\text { identifying and reporting suspicious and unusual transactions, and monitoring } \\
\text { cross-border wire transfers. } \\
\text { - Require MVT service operators to keep current lists of their agents and make them } \\
\text { available to the designated competent authority. } \\
\text { - Introduce sanctions for MVT service operators' breaches of their AML/CFT } \\
\text { obligations. } \\
\text { - Assess the potential informal MVT system operating in the country and take } \\
\text { measures to address the risks, if any. }\end{array}$ \\
\hline \multicolumn{3}{|r|}{ Preventive Measures: Non-Financial Businesses and Professions } \\
\hline
\end{tabular}




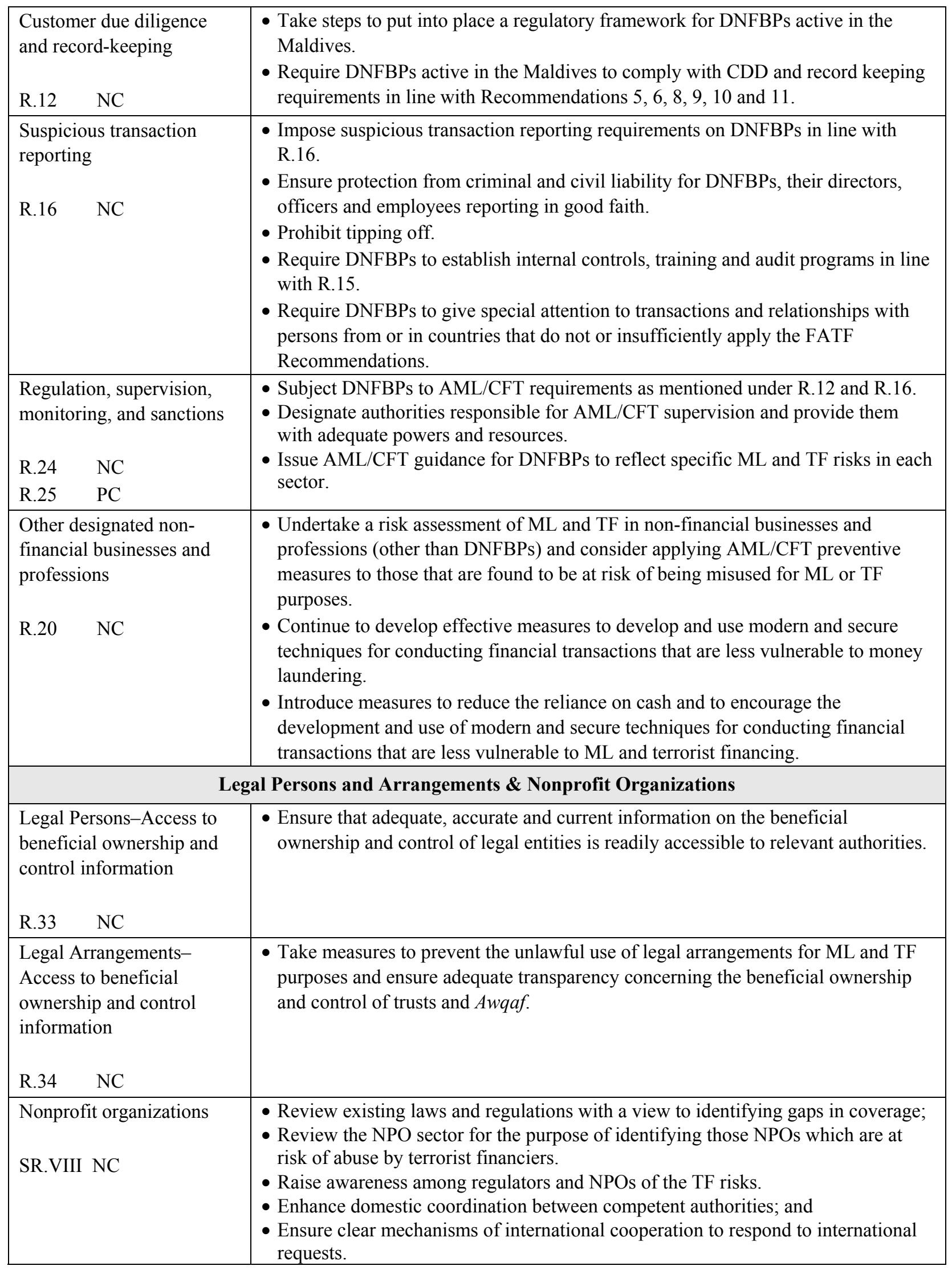




\begin{tabular}{|c|c|c|}
\hline \multicolumn{3}{|r|}{ National and International Cooperation } \\
\hline \multicolumn{2}{|c|}{$\begin{array}{l}\text { National cooperation and } \\
\text { coordination }\end{array}$} & \multirow[t]{2}{*}{ - Make better use of the AML/CFT Steering Committee. } \\
\hline R.31 & $\mathrm{PC}$ & \\
\hline \multicolumn{2}{|c|}{$\begin{array}{l}\text { The Conventions and UN } \\
\text { Special Resolutions }\end{array}$} & \multirow[t]{3}{*}{$\begin{array}{l}\text { - Become party to the Palermo Convention, and fully implement the Vienna and } \\
\text { Palermo Conventions, the ICSFT and the relevant UNSCRs. }\end{array}$} \\
\hline R.35 & $\mathrm{PC}$ & \\
\hline SR.I & $\mathrm{NC}$ & \\
\hline $\begin{array}{l}\text { R.36 } \\
\text { R.37 } \\
\text { R.38 } \\
\text { SR.V }\end{array}$ & egal Assistance & $\begin{array}{l}\text { - Criminalize ML and TF in line with the standard. } \\
\text { - Establish a comprehensive framework to allow for the widest possible range of } \\
\text { MLA in ML and/or TF investigations, prosecutions and related proceedings. In } \\
\text { doing so, ensure that MLA can be rendered in a timely, constructive and effective } \\
\text { manner, and that it is not subject to unreasonable, disproportionate or unduly } \\
\text { restrictive conditions. } \\
\text { - Ensure that, where legal professional privilege does not apply, MLA is not refused } \\
\text { on the grounds of secrecy or confidentiality laws for FIs and DNFBPs. } \\
\text { - Ensure that the powers of competent authorities required under R.28 are also } \\
\text { available for use in response to requests for MLA. } \\
\text { - Ensure that, to the greatest extent possible, MLA may be rendered in the absence } \\
\text { of dual criminality for less intrusive and non compulsory measures. } \\
\text { - Establish a legal framework for effective and timely responses to requests for } \\
\text { freezing, seizing and confiscating assets in line with R.38. }\end{array}$ \\
\hline \multicolumn{2}{|c|}{ Extradition } & \multirow{4}{*}{$\begin{array}{l}\text { - Criminalize ML and TF in line with the standard and ensure that both are } \\
\text { extraditable offenses. } \\
\text { - Establish a legal framework to enable the extradition, without undue delay, of } \\
\text { individuals charged with a ML offense and/or TF. }\end{array}$} \\
\hline R.39 & $\mathrm{NC}$ & \\
\hline R.37 & $\mathrm{PC}$ & \\
\hline SR.V & $\mathrm{NC}$ & \\
\hline \multicolumn{2}{|c|}{$\begin{array}{l}\text { Other Forms of } \\
\text { Cooperation }\end{array}$} & \multirow{3}{*}{$\begin{array}{l}\text { - Introduce legal authority for the MMA to cooperate with its foreign counterparts } \\
\text { (including outside the banking sector). } \\
\text { - Establish the FIU on a sound legal basis and authorize it to exchange information } \\
\text { with its foreign counterparts. }\end{array}$} \\
\hline R.40 & $\mathrm{PC}$ & \\
\hline SR.V & $\mathrm{NC}$ & \\
\hline \multicolumn{3}{|r|}{ Other Issues } \\
\hline \multicolumn{2}{|c|}{ Resources \& Statistics } & \multirow{3}{*}{$\begin{array}{l}\text { - Increase the MMA and the CMDA's human resources as well as expertise in } \\
\text { support of their supervisory function. } \\
\text { - Increase the PGO, and the judiciary's resources and training in AML/CFT matters. } \\
\text { - Provide training on AML/CFT matters to all relevant authorities. }\end{array}$} \\
\hline R.30 & $\mathrm{PC}$ & \\
\hline R.32 & $\mathrm{NC}$ & \\
\hline \multicolumn{2}{|c|}{$\begin{array}{l}\text { Other relevant } \mathrm{AML} / \mathrm{CFT} \\
\text { measures or issues }\end{array}$} & $\begin{array}{l}\text { - Ensure that revised Penal Code is adopted and that criminal procedure rules are set } \\
\text { out in law in order to enable the authorities to fight against ML and TF in an } \\
\text { effective way. }\end{array}$ \\
\hline \multicolumn{2}{|c|}{$\begin{array}{l}\text { General framework - } \\
\text { structural issues }\end{array}$} & $\bullet$ \\
\hline
\end{tabular}

